\title{
Cyclic feeding of low and high protein diets reduces production cost of Labeo rohita (Hamilton, 1822)
}

\author{
BIJI XAVIER ${ }^{* 1,2}$, K. K. JAIN ${ }^{1}$, N. P. SAHU ${ }^{1}$, A. K. PAL ${ }^{1}$ AND G. MAHESWARUDU ${ }^{3}$ \\ ${ }^{1}$ ICAR-Central Institute of Fisheries Education, Versova, Mumbai - 400 061, Maharashtra, India \\ ${ }^{2}$ Visakhapatnam Regional Centre of ICAR-Central Marine Fisheries Research Institute, Pandurangapuram \\ Visakhapatnam - 530 003, Andhra Pradesh, India \\ ${ }^{3}$ ICAR-Central Marine Fisheries Research Institute, P B No. 1603, Ernakulam North P. O., Kochi - 682018 \\ Kerala, India \\ e-mail: bijicmfri@gmail.com
}

\begin{abstract}
Eighty four days feeding trial ( 3 feeding cycle; each cycle of 28 days comprising 21 days with low protein and 7 days with normal or high protein diets) was conducted with Labeo rohita fingerlings to investigate the growth performance. Four diets; $\mathrm{D}_{1}(10 \%$ $\mathrm{CP}) ; \mathrm{D}_{2}(30 \% \mathrm{CP}) ; \mathrm{D}_{3}(35 \% \mathrm{CP})$ and $\mathrm{D}_{4}(40 \% \mathrm{CP})$ were prepared. A total of 225 fingerlings were distributed randomly into five treatments in triplicates. $\mathrm{T}_{1}$ and $\mathrm{T}_{2}$ groups were fed with $\mathrm{D}_{1}$ and $\mathrm{D}_{2}$ diets respectively throughout the experimental period. The feeding cycle of 28 days consisted of 21 days feeding with $\mathrm{D}_{1}$ and 7 days with $\mathrm{D}_{2}\left(\mathrm{~T}_{3}\right) ; \mathrm{D}_{3}\left(\mathrm{~T}_{4}\right)$ or $\mathrm{D}_{4}\left(\mathrm{~T}_{5}\right)$. Higher growth rate in terms of specific growth rate, feed conversion ratio and apparent net protein utilisation were found in $\mathrm{T}_{2}$ and $\mathrm{T}_{3}$ group compared to $\mathrm{T}_{4}$ and $\mathrm{T}_{5}$. However, protein efficiency ratio of $\mathrm{T}_{3}$ group was significantly higher than the $\mathrm{T}_{2}$ group ( $<0.05$ ). Highest and lowest content of protein and lipid was observed in $\mathrm{T}_{2}$ group, whereas, the ash content was highest in $\mathrm{T}_{1}$ group. Feeding cost was considerably reduced with $\mathrm{T}_{3}$ group of low protein intake (43.63\%) registering $20.17 \%$ saving in production cost. The results indicate that fish fed with cyclic feeding schedule of 21 days with $\mathrm{D}_{1}(10 \% \mathrm{CP})$ followed by 7 days with a normal diet, $\mathrm{D}_{2}(30 \% \mathrm{CP})$ could reduce the production cost with considerable savings in feed cost.
\end{abstract}

Keywords: Cyclic feeding schedule, Dietary protein level, Feed cost, Labeo rohita, Production cost, Protein utilisation

\section{Introduction}

Feed is the major input in terms of cost in fish culture, that invites the attention of nutritionists to reduce the cost by optimising the most expensive nutrient protein (Wee and Wang, 1987) either through proper formulation or adopting economic feeding strategies. The cost of feed is largely influenced by protein in terms of its level of inclusion and its source. The reduction of feed cost by the substitution of fishmeal by cheaper protein sources is the possible alternate approach (Tacon and Jackson, 1985; Kaushik, 1989). Use of locally available ingredients through proper processing methods in order to improve the nutritional quality for feed preparation is recommended even by FAO (Anon., 1993). The efficacy of various plant protein sources for partial or complete replacement of fishmeal in aqua-feeds has been investigated by a number of workers (Atack and Matty, 1979; Viola et al., 1982; Tacon, 1993; Ray and Das, 1995).

Another approach to reduce feed cost is the management in feeding (Singh and Srivatava, 1984, 1985). Published reports state that feeding of fish with same level of protein every day is not economical (De Silva, 1985) and strategy of cyclic/mixed feeding schedule resulted in better nutrient utilisation. Application of mixed feeding schedules in feed cost reduction and nutrient utilisation improvement is reported in different fish species like Indian major carps, Catla catla and Labeo rohita (Nandeesha et al., 1993, 1994); common carp, Cyprinus carpio (Srikanth et al., 1989; Nandeesha et al., 1995, 2002); Nile tilapia, Oreochromis niloticus (Patel and Yakupitiyage, 2003); Sutchi catfish, Pangasius hypophthalmus; and silver carp, Hypophthalmichthys molitrix (Ali et al., 2005).

Labeo rohita is the most preferred species constituting about $35 \%$ of the total Indian major carps production (FAO, 2000). L. rohita is a herbivorous species and primarily prefers to feed on plant materials (Talwar and Jhingran, 1991). Feeding of $30 \%$ crude protein (CP) may not be required for rohu fingerlings on day to day basis as reported for other species. Hence, cyclic feeding of low protein diet followed by a normal or high protein diet may be an ideal strategy to reduce the production cost. There is scanty information on this aspect and therefore, the present experiment was conducted with the objective to select an ideal feeding strategy for economic production of $L$. rohita fingerlings 


\section{Materials and methods}

The experiment was conducted for 84 days using fingerlings of $L$. rohita $(5.45 \pm 0.03 \mathrm{~g})$. The fingerlings were brought from fish seed farm at Kosamba in Gujarat and acclimated to the experimental condition for one month. Fifteen fishes were stocked in each tub (100 l capacity) with continuous aeration. Feed was formulated and prepared by weighing all ingredients and mixing in a big bowl to get homogenous mixture. Dough was made with the addition of sufficient water and oil was added to the dough for uniform distribution. Steaming of the dough was done for $10 \mathrm{~min}$ in a pressure cooker and vitamin-mineral premix (EmixTM plus, India) along with vitamin $\mathrm{C}$ was added after cooling. Uniform sized pellets were made with hand pelletiser and pellets were dried in oven at $50^{\circ} \mathrm{C}$ after air drying for $4 \mathrm{~h}$. The completely dried pellets were packed in airtight labeled polythene bags and stored at $4{ }^{\circ} \mathrm{C}$ until use. Fingerlings were fed to apparent satiation twice a day at $0900 \mathrm{hrs}$ in the morning and $1800 \mathrm{hrs}$ in the evening. Cleaning of the experimental tubs were done every day by siphoning out the water along with faecal matter and left over feed and same volume of water was replaced with fresh bore well water free of chlorine.

\section{Feeds and feeding schedules}

Experimental diet formulation and its proximate composition are given in Table 1. Four diets were prepared viz., $\mathrm{D}_{1}(10 \% \mathrm{CP}) ; \mathrm{D}_{2}(30 \% \mathrm{CP}) ; \mathrm{D}_{3}(35 \% \mathrm{CP})$ and $\mathrm{D}_{4}(40 \%$ $\mathrm{CP})$. The feeding trial was conducted with five treatments $\left(\mathrm{T}_{1}\right.$ to $\left.\mathrm{T}_{5}\right)$ in triplicate. The feeding schedules followed included a cycle of 28 days, which consisted of 21 days of feeding with $\mathrm{D}_{1}$ and 7 days with $\mathrm{D}_{2}, \mathrm{D}_{3}$ or $\mathrm{D}_{4}$. The treatments were $T_{1}\left(D_{1}\right.$ fed group); $T_{2}\left(D_{2}\right.$ fed group) and three cyclic feeding schedules viz. $\mathrm{T}_{3}\left(21\right.$ days feeding with $\mathrm{D}_{1}$ and 7 days feeding with $\left.\mathrm{D}_{2}\right), \mathrm{T}_{4}\left(21\right.$ days feeding with $\mathrm{D}_{1}$ and 7 days feeding with $\mathrm{D}_{3}$ ) or $\mathrm{T}_{5}\left(21\right.$ days feeding with $\mathrm{D}_{1}$ and 7 days feeding with $\mathrm{D}_{4}$ ). The fish were fed for 84 days.

Growth study

Growth was assessed at each cycle $\left(21^{\text {st }}\right.$ and $28^{\text {th }}$ day) by bulk weighing of fingerlings in each tub and performance was evaluated in terms of WG (weight gain \%), SGR (specific growth rate) and feed utilisation parameters like FCR (feed conversion ratio), FCE (feed conversion efficiency), PER (protein efficiency ratio) and ANPU (apparent net protein utilisation) calculated using the following standard formulae:

$$
\begin{array}{ll}
\text { WG }(\text { Weight gain }) \%= & \begin{array}{l}
\text { weight } \times 100 \\
100(\ln \text { average final weight }-\ln
\end{array} \\
\text { SGR } & \begin{array}{l}
\text { average initial weight }) / \text { No. of culture } \\
\text { days }
\end{array}
\end{array}
$$

Table 1. Experimental diet formulation and its proximate composition

\begin{tabular}{lllll}
\hline Ingredients (\%) & \multicolumn{3}{c}{ Experimental diets } \\
\cline { 2 - 4 } & $\mathrm{D}_{1}(10 \% \mathrm{CP})$ & $\mathrm{D}_{2}(30 \% \mathrm{CP})$ & $\mathrm{D}_{3}(35 \% \mathrm{CP})$ & $\mathrm{D}_{4}(40 \% \mathrm{CP})$ \\
\hline Fish meal & - & 15.00 & 20.00 & 25.00 \\
Soybean & 2.00 & 36.00 & 41.00 & 48.00 \\
Rice bran & 40.00 & 12.00 & 9.00 & 5.00 \\
Wheat bran & 36.00 & 15.00 & 9.00 & 5.00 \\
Wheat flour & 15.00 & 15.00 & 14.00 & 10.00 \\
Cod liver oil: Sunflower oil (1:2) & 5.00 & 5.00 & 5.00 & 5.00 \\
CMC & 0.50 & 0.50 & 0.50 & 0.50 \\
Vitamin-mineral mix & $*$ * & 1.40 & 1.40 & 1.40 \\
Vitamin C & 1.40 & 0.10 & 0.10 & 0.10 \\
Total & 0.10 & 100.0 & 100.0 & 100.0 \\
\hline Proximate composition of the diets (\% DM) & 100.0 & & & 90.54 \\
Organic matter & & 90.80 & 90.61 & 41.22 \\
Protein & 90.78 & 30.86 & 35.96 & 5.55 \\
Lipid & 12.79 & 5.29 & 5.26 & 9.23 \\
Ash & 5.66 & 9.82 & 9.46 & 10.23 \\
Crude fiber & 15.14 & 11.45 & 10.53 & 33.77 \\
Nitrogen free Extract & 16.32 & 42.58 & 38.79 & 390.83 \\
Gross energy (kcal $\left.100 \mathrm{~g}^{-1}\right)$ & 50.49 & 387.17 & 388.46 & \\
\hline
\end{tabular}

$\mathrm{CMC}^{*}=$ Carboxy methyl cellulose,

Vitamin-mineral mix ${ }^{* *}=$ Composition of vitamin mineral mix (EMIX PLUS) (quantity/2.5 kg): Vitamin A 55,00,000 IU; Vitamin D $1,100,000 \mathrm{IU}$; Vitamin B 2,000 mg; Vitamin E 750 mg; Vitamin K 1,000 mg; Vitamin B 1,000 mg; Vitamin B 6 mcg; Calcium Pantothenate 2,500 mg; Nicotinamide 10 g; Choline chloride 150 g; Mn 27,000 mg; I 1,000 mg; Fe 7,500 mg; Zn 5,000 mg; Cu 2,000 mg; Co 450 mg; Ca 500 g; P 300 g; L-lysine 10 g; DL-methionine $10 \mathrm{~g}$; Selenium 50 ppm; Selenium 50 ppm; Satwari 250 ppm. 
PER

ANPU

Survival \% Total wet weight gain (g)/Crude protein fed $(\mathrm{g})$

$=($ Final tissue protein-Initial tissue protein)/ Protein fed x100

(Final no. of fish harvested/Initial no.

Diet and tissue analysis

Proximate composition of the diets and whole fish were analysed following the standard methods of AOAC (1995) at the beginning and end of the feeding trial. Moisture content was determined by drying the samples at $105^{\circ} \mathrm{C}$ to a constant weight. Nitrogen content was analysed by Kjeltec $(2200$ Kjeltec auto distillation, Foss Tecator, Sweden) and crude protein $(\mathrm{CP})$ content was estimated by multiplying nitrogen percentage by 6.25 . Ether extract (EE) was analysed by Soxtec (1045, Soxtec extraction unit, Tecator, Sweden) using diethyl ether (boiling point, $40-60^{\circ} \mathrm{C}$ ) as a solvent and ash content was estimated by incinerating the samples in a muffle furnace at $600^{\circ} \mathrm{C}$ for $6 \mathrm{~h}$. Total carbohydrate was calculated using the following formula:

$$
\text { Total carbohydrate }(\%)=100-(\mathrm{CP} \%+\mathrm{EE} \%+\mathrm{Ash} \%) .
$$

The digestible energy (DE) value was calculated as per Halver (1976).

\section{Economics and statistical analysis}

The cost of each feed was computed from the prevailing market prices of ingredients without taking any other expenditure into account. The total feed and feeding cost for each treatment was determined and calculated for the savings in terms of protein intake and production cost (Table 4). For calculation of economics, the cost incurred in case of $\mathrm{T}_{2}$ group was compared with other groups.

The software SPSS version 14.0 was used for the statistical analysis of the data. The treatment effects were compared with ANOVA and comparison among the means was made using Duncan's multiple range tests (1955)

\section{Results and discussion}

\section{Growth performance}

Growth rate of fingerlings (Table 2) during experimental period of 56 days (Fig. 1 and 2) was similar in all treatment groups and $\mathrm{T}_{5}$ fed group exhibited the lowest growth rate among the entire schedule. Similar pattern was also recorded for SGR. Highest weight gain (WG \%) was recorded in group fed with $\mathrm{T}_{3}$, which was not different from $\mathrm{T}_{2}$ group $(\mathrm{p}>0.05)$.

In the present experiment, 21 days feeding of fingerlings with low protein diet continued by 7 days feeding with normal protein diet $\left(\mathrm{T}_{3}\right)$ was found to be equally effective and comparable to fingerlings fed continuously with $30 \%$ $\mathrm{CP}\left(\mathrm{T}_{2}\right)$. It appears that feeding $30 \%$ protein daily in the diet or cyclic feeding of $10 \% \mathrm{CP}$ for 21 days followed by $30 \%$ CP for 7 days were equally effective for growth in L. rohita fingerlings. This reveals that normal protein diet is not necessary for daily feeding as the protein requirement of a species is an average figure of an extended period. Hence adopting cyclic feeding schedule of variable protein levels for short duration may satisfy the requirement. Beneficial

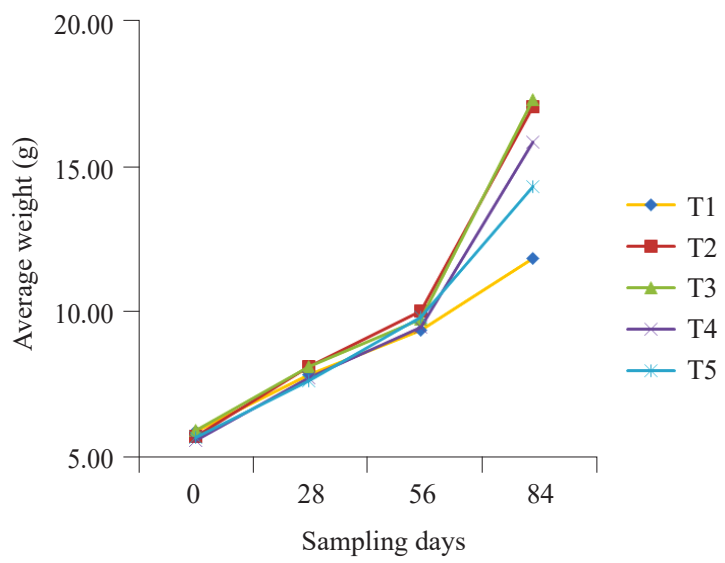

Fig. 1. The average growth of L. rohita fingerlings at the end of each cyclic feeding schedule

Table 2. The growth performance of fingerlings maintained on cyclic feeding schedule for 84 days

\begin{tabular}{|c|c|c|c|c|c|}
\hline \multirow{2}{*}{ Parameters } & \multicolumn{5}{|c|}{ Feeding schedules } \\
\hline & $\mathrm{T}_{1}$ & $\mathrm{~T}_{2}$ & $\mathrm{~T}_{3}$ & $\mathrm{~T}_{4}$ & $\mathrm{~T}_{5}$ \\
\hline Initial body weight (g) & $5.65 \pm 0.01$ & $5.65 \pm 0.04$ & $5.65 \pm 0.03$ & $5.46 \pm 0.03$ & $5.57 \pm 0.04$ \\
\hline Final body weight (g) & $11.79^{\mathrm{a}} \pm 0.06$ & $17.06^{\mathrm{d}} \pm 0.01$ & $17.31^{\mathrm{d}} \pm 0.07$ & $15.83^{\mathrm{c}} \pm 0.03$ & $14.31^{\mathrm{b}} \pm 0.05$ \\
\hline WG $(\%)$ & $109.56^{\mathrm{a}} \pm 1.42$ & $206.02^{\mathrm{d}} \pm 2.30$ & $209.11^{\mathrm{d}} \pm 2.54$ & $189.85^{\mathrm{c}} \pm 2.62$ & $156.69^{\mathrm{b}} \pm 1.47$ \\
\hline SGR (\% day) & $2.45^{\mathrm{a}} \pm 0.01$ & $2.82^{\mathrm{d}} \pm 0.01$ & $2.83^{\mathrm{d}} \pm 0.01$ & $2.74^{\mathrm{c}} \pm 0.01$ & $2.64^{b} \pm 0.01$ \\
\hline FCR & $3.77^{\mathrm{d}} \pm 0.05$ & $2.09^{\mathrm{a}} \pm 0.02$ & $2.00^{\mathrm{a}} \pm 0.04$ & $2.23^{\mathrm{b}} \pm 0.01$ & $2.69^{c} \pm 0.04$ \\
\hline PER & $1.62^{\mathrm{a}} \pm 0.02$ & $1.87^{\mathrm{b}} \pm 0.03$ & $2.64^{\mathrm{d}} \pm 0.08$ & $2.23^{\mathrm{c}} \pm 0.01$ & $1.71^{\mathrm{a}} \pm 0.02$ \\
\hline ANPU (\%) & $15.12^{\mathrm{a}} \pm 0.24$ & $34.67^{\mathrm{d}} \pm 0.77$ & $34.52^{\mathrm{d}} \pm 0.77$ & $30.20^{c} \pm 0.09$ & $21.62^{b} \pm 0.47$ \\
\hline Survival rate (\%) & 100 & 100 & 100 & 100 & 100 \\
\hline
\end{tabular}

Mean values bearing different superscripts in a row are significantly different $(\mathrm{p}<0.05)$ 


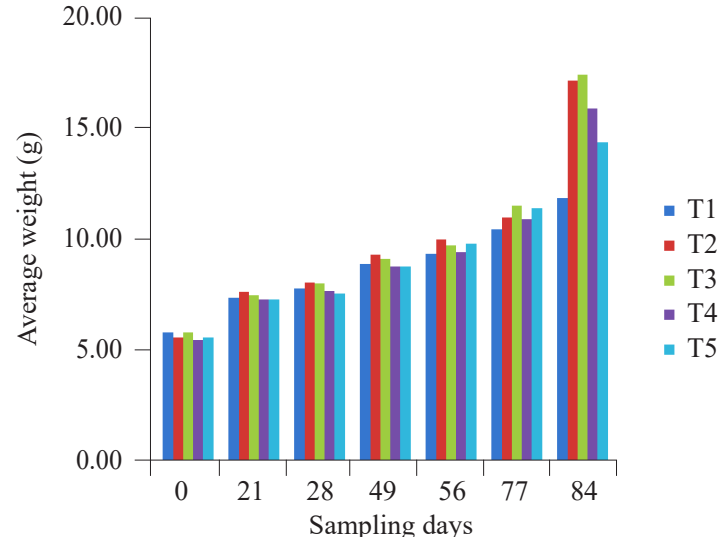

Fig. 2. Average weight of $L$. rohita fingerlings at each sampling days over 84 days

effect of mixed/cyclic feeding schedule as suitable strategy has been reported in common carp (Srikanth et al., 1989; Nandeesha et al., 1993).

FCR and PER were also significantly influenced by the different feeding schedules. Lowest FCR was observed in $\mathrm{T}_{3}$, which was not different from $\mathrm{T}_{2}$, whereas highest FCR was recorded in $T_{1}$ group. The highest PER was recorded in $\mathrm{T}_{3}$ and lowest in $\mathrm{T}_{5}$, which was not different $(\mathrm{p}>0.05)$ from $\mathrm{T}_{1}$ group. However, the highest ANPU was recorded in $\mathrm{T}_{3}$, which was not different from $T_{2}(p>0.05)$. The ANPU value gradually decreased with higher protein feed fed in $\mathrm{T}_{4}$ and $\mathrm{T}_{5}$. Lowest ANPU value was found in $\mathrm{T}_{1}$ group.

The present study showed that the SGR, FCR and ANPU in L. rohita fingerlings were influenced by the different feeding schedules. $\mathrm{T}_{3}$ fed fingerlings performed maximum growth, which was comparable to fingerlings fed with diet of $30 \% \mathrm{CP}\left(\mathrm{T}_{2}\right)$. Similar ANPU values in both the treatment groups suggests that the nutrient utilisation was similar in both groups. $\mathrm{T}_{3}$ fed group recorded more PER value than $T_{2}$ group, due to less protein fed to the $T_{3}$ group. As protein content increased in the $\mathrm{T}_{4}$ and $\mathrm{T}_{5}$ fed groups, PER and ANPU values decreased which proved that at higher inclusion level, the protein utilisation would be less. Similar studies have been reported in common carp (Nandeesha et al., 1995, 2002).

\section{Muscle tissue composition}

Proximate composition of muscle tissue of rohu fingerlings maintained on different feeding schedules is presented in Table 3. Among the different feeding schedules, highest $(\mathrm{p}<0.05)$ moisture content was observed in $\mathrm{T}_{1}$ and lowest in $\mathrm{T}_{2}$ group. Lowest protein and lipid content were recorded in $\mathrm{T}_{1}$ group, whereas highest protein and lipid content was observed in $T_{2}$ group. There was no significant difference in values of lipid content in the muscle of fingerlings fed under various feeding schedules. Highest ash content was recorded in $\mathrm{T}_{1}$ group and there was no significant difference among the rest of the groups.

Proximate composition of muscle tissue of $L$. rohita fingerlings, maintained on cyclic feeding schedule for 84 days varied considerably among the treatments. Highest content of protein and fat in fish muscle was recorded in $\mathrm{T}_{2}$ group. The protein and fat deposition in fish muscle was found to clearly correlate with the growth pattern of the group. Fingerlings fed with lowest protein level $\left(\mathrm{T}_{1}\right)$ exhibited lowest fat accumulation and this finding was similar to the experiment with common carp (Srikanth et al., 1989; Nandeesha et al., 2002).

\section{Economics}

Economics of various feeding schedules for L. rohita fingerlings is presented in Table 4 . It is evident from various parameters that, the feeding $\cos$ for $\mathrm{T}_{3}$ was minimum when compared to the other feeding schedules. The feed cost for $T_{1}$ was the least. The cost of production i.e. feeding cost for the production of unit weight of fish was also minimum for $T_{3}$. Thus, the $T_{3}$ group showed production at less feed cost and minimum protein intake with saving of production cost to the extent of $20.17 \%$. Production cost increased up to $35.38 \%$ when fed with $\mathrm{T}_{5}$. The protein intake of $\mathrm{T}_{3}$ also significantly reduced to $43.63 \%$ compared to $\mathrm{T}_{2}$.

Overall the results indicated that cyclic feeding of 28 days comprising 21 days feeding of low protein (10\%) followed by a normal protein diet $(30 \%)$ for 7 days led to growth rate similar to the normal protein fed group $(30 \%)$ continuously. Adopting this feeding strategy helps to save protein to the extent of $43.63 \%$, which translates into an economic saving of production cost to the extent of $20.17 \%$. With the adoption

Table 3. Proximate composition of muscle tissue (\% wet weight) of L. rohita fingerlings at the end of the experiment

\begin{tabular}{llllll}
\hline \multirow{2}{*}{ Proximate composition } & \multicolumn{5}{c}{ Treatments } \\
\cline { 2 - 6 } & $\mathrm{T}_{1}$ & $\mathrm{~T}_{2}$ & $\mathrm{~T}_{3}$ & $\mathrm{~T}_{4}$ & $\mathrm{~T}_{5}$ \\
\hline Moisture & $76.21^{\mathrm{d}} \pm 0.13$ & $73.90^{\mathrm{a}} \pm 0.20$ & $74.74^{\mathrm{b}} \pm 0.13$ & $75.46^{\mathrm{c}} \pm 0.12$ & $75.52^{\mathrm{c}} \pm 0.08$ \\
Protein & $12.72^{\mathrm{a}} \pm 0.08$ & $16.46^{\mathrm{e}} \pm 0.13$ & $15.86^{\mathrm{d}} \pm 0.04$ & $14.49^{\mathrm{b}} \pm 0.10$ & $14.86^{\mathrm{c}} \pm 0.06$ \\
Lipid & $2.41^{\mathrm{a}} \pm 0.013$ & $3.32^{\mathrm{c}} \pm 0.023$ & $2.60^{\mathrm{b}} \pm 0.013$ & $2.61^{\mathrm{b}} \pm 0.013$ & $2.62^{\mathrm{b}} \pm 0.01$ \\
Ash & $3.77^{\mathrm{b}} \pm 0.081$ & $3.06^{\mathrm{a}} \pm 0.104$ & $3.04^{\mathrm{a}} \pm 0.026$ & $3.02^{\mathrm{a}} \pm 0.012$ & $3.07^{\mathrm{a}} \pm 0.012$ \\
\hline
\end{tabular}

Mean values bearing different superscripts in a row are significantly $(\mathrm{p}<0.05)$ different 
Table 4. Economics of cyclic feeding schedule for L. rohita fingerlings maintained for 84 days

\begin{tabular}{llllll}
\hline Parameters & $\mathrm{T}_{1}$ & $\mathrm{~T}_{2}$ & $\mathrm{~T}_{3}$ & $\mathrm{~T}_{4}$ & $\mathrm{~T}_{5}$ \\
\hline Feed intake $(\mathrm{g})$ & 23.35 & 24.19 & 24.17 & 23.12 & 23.67 \\
Feeding cost $\left(₹ \mathrm{~g}^{-1}\right)$ & 0.14 & 0.19 & 0.16 & 0.17 & 0.19 \\
Weight gain $(\mathrm{g})$ & 6.14 & 11.41 & 11.66 & 10.37 & 8.74 \\
Cost of production $\left(₹ \mathrm{~kg}^{-1}\right)$ & 22.82 & 16.96 & 13.47 & 16.72 & 22.34 \\
Protein intake $(\mathrm{g})$ & 2.99 & 7.47 & 4.55 & 4.74 & 5.27 \\
\hline
\end{tabular}

Feed cost: $10 \%$ CP- ₹ $6.00 ; 30 \%$ CP- ₹ $8.00 ; 35 \%$ CP - ₹ $12.00 ; 40 \%$ CP- ₹ 15.00 .

Feeding cost $(₹)=$ Feed intake $(\mathrm{g}) \mathrm{x}$ cost of feed $(₹)$

Cost of production $=($ Feeding cost $(₹) /$ Weight gain $(\mathrm{g})) \times 1000$

Protein intake $=$ Feed intake $(\mathrm{g}) \times \mathrm{CP} \%$ of the feed

Cost saving $=[($ Feeding cost of Control B - Feeding cost of respective schedule $) /$ Feeding cost of control B $]$ x 100

of this feeding strategy, survival and proximate composition also was not affected much, which proved that feeding a low protein diet followed by normal diet may be an ideal strategy for reducing the production cost in finfish culture. However, long term studies need to be undertaken further as there are few reports on this aspect.

\section{Acknowledgements}

The authors are thankful to the Director, ICAR-CIFE, Mumbai, India for providing all the facilities required for the present work.

\section{References}

Ali, M. Z., Hossain, M. A. and Mazid, M. A. 2005. Effect of mixed feeding schedules with varying dietary protein levels on the growth of sutchi catfish, Pangasius hypophthalmus (Sauvage) with silver carp, Hypophthalmichthys molitrix (Valenciennes) in ponds. Aquac. Res., 36: 627-634.

Anon. 1993. Recommendations in the Proceedings of the FAO/ AADCP. Regional Consultation on farm-made aquafeeds, 14-18 December, 1992. Bangkok, Thailand. In: New M. B., Tacon, A. G .J., Csavas, I. (Eds.), Farm-made aquafeeds. RAPA Publication 1993/18, AADCP/PROC/5, Publ. FAO Regional Office for Asia and the Pacific.

AOAC 1995. Official methods of analysis of AOAC International, vol. $1,16^{\text {th }}$ edn., Association of Official Agricultural Chemists, Arlington, USA

De Silva, S. S. 1985. Performance of Oreochromis niloticus (L.) fry maintained on mixed feeding schedules of different protein content. Aquacu. Fish. Manage., 16: 331-340.

Duncan, G. B. 1955. Multiple range and multiple F-tests. Biometrics, 11: $1-42$.

FAO 2000. Fishery statistics (Aquaculture production), 90/2: 22-26,36,114,131. Food and Agriculture Organization of the united Nations, Rome, Italy,

Halver, J. E. 1976. The nutritional requirements of cultivated warm water and coldwater fish species. Paper no. 31. FAO Technical Conference on Aquaculture, Kyoto, 26 May to 2 June, 9 pp.
Kaushik, S. J. 1989. Use of alternate protein sources for intensive rearing of carnivorous fishes. In: Shiau, S.Y. (Ed.), Progress in fish nutrition, marine food science series, No. 9, Keeking, ROC, Taiwan, p.191-201.

Nandeesha, M. C., Silva, S. S. and Krishna M. D. 1993. Evaluation of mixed feeding schedules in two Indian major carps, catla (Catla catla) and rohu (Labeo rohita). In: Kaushik, S. J. and Luquet, P. (Eds.), Fish nutrition in practice. INRA Editions, Paris, France, p. 753-765.

Nandeesha, M. C., Silva S. S., Krishna, M. D. and Dathatri, K. 1994. Use of mixed feeding schedules in fish culture. I. Field trials on catla, Catla catla (Hamilton-Buchanan) rohu, L. rohita (Hamilton) and common carp, Cyprinus carpio L. Aquac. Fish. Manage, 25: 659-670.

Nandeesha, M. C., Silva, S. S. and Krishna, M. D. 1995. Use of mixed feeding schedules in fish culture: performance of common carp, Cyprinus carpio L., on plant and animal based diets. Aquac. Res., 26: 161-166.

Nandeesha, M. C., Gangadhara, B. and Manissery, J. K. 2002. Further studies on the use of mixed feeding schedules with plant and animal based diets for common carp Cyprinus carpio (Linnaeus). Aquac. Res., 33: 1157-1162.

Patel, A. B. and Yakupitiyage, A. 2003. Mixed feeding schedules in semi-intensive pond culture of Nile tilapia, Oreochromis niloticus, L.: Is it necessary to have two diets of differing protein contents? Aquac. Res., 34: 1343-1352.

Ray, A. K. and Das, I. 1995. Evaluation of dried aquatic weed, Pistia stratiotes meal as a feedstuff in pelleted feed for rohu, L. rohita fingerlings. J. Appl. Aquac., 5(4): 35-44.

Singh, R. P. and Srivastava, A. K. 1984. Effect of feeding frequency on the growth, consumption and gross conversion efficiency in the siluroid catfish, Heteropneustes fossilis (Bloch). Isr. J. Aquac. Bamidgeh, 36: 80-91.

Singh, R. P. and Srivastava, A. K. 1985. Effect of different ration levels on the growth and gross conversion efficiency in a silurid catfish, Heteropneustes fossilis (Bloch). Bull. Inst. Zool. Acad. Sin., 24: 69-74.

Srikanth, G. K., Nandeesha, M. C., Keshavnath, P., Varghese, T. J., Shetty, H. P. C. and Basavaraja, N. 1989. On the applicability of mixed feeding schedule for common carp, Cyprinus 
carpio var. communis. In: Huisman, E. A., Zonneveld, N. and Boumans, A. H. M. (Eds.), Aquaculture research in Asia: management techniques and nutrition. Centre for Agriculture Publishing and Documentation, Pudoc, Wageningen, Netherlands, p. 254-260.

Tacon, A. G. J. 1993. Feed ingredients for warm water fish: Fish meal and other processed feed stuffs. FAO Fisheries Circular No. 856, Food and Agricultural Organisation, Rome, Italy.

Tacon, A. G. J and Jackson, A. J. 1985. Utilisation of conventional and unconventional protein sources in practical fish feeds. In: Cowey, C. B., Mackie, A. M. and Bell, J. G. (Eds.),
Nutrition and feeding in fish. Academic Press, London, p. 119-145.

Talwar, P. K. and Jhingran, A. G. 1991. Inland fishes of india and adjacent countries, vol. I. Oxford and IBH Publishing Co. Pvt. Ltd., New Delhi, India.

Viola, S., Mokady, S., Rappaport, U. and Arieli, Y. 1982. Partial or complete replacement of fish meal by soybean meal in feeds for intensive culture of carps. Aquaculture, 26: 223-226.

Wee, K. L. and Wang, S. S. 1987. Nutritive value of Leucaena leaf meal in pelleted feed for Nile tilapia. Aquaculture, 62: 97-108. 